\title{
Gnaphosid Spiders mainly from the Daisetsuzan Mountains, Hokkaido, Japan
}

\author{
Hirotsugu $\mathrm{ONO}^{1)}$ \\ 小野展嗣 ${ }^{1)}$ ：お打に大雪山から得られた北海道のワシグモ科クモ類
}

\begin{abstract}
Ten species of spiders of the family Gnaphosidae of Hokkaido, Japan, collected mainly from the Daisetsuzan Mountains, are reported. Of these, Drassyllus shaanxiensis Platnick et Song, 1986, and D. sasakawai Kamura, 1987, are newly registered to the fauna of Hokkaido, and Micaria alpina L. КосH, 1872, and Gnaphosa sticta KulCZYŃSKI, 1908, are recorded from Japan for the first time. The female genitalia and the male palps of the latter two species are illustated on the basis of the Japanese materials. Micaria alpina are widely distributed in the northernmost part of the Holarctic regions, while Gnaphosa sticta is known only from northeastern Siberia and Hokkaido. The specimens of the spiders were collected by bait trapping.
\end{abstract}

Up to the present, 15 species of spiders of the family Gnaphosidae were recorded from Hokkaido, the northernmost main island of Japan, that is, Micaria japonica Hayashi, 1985 [MATsuda (1987, 1988), Chikuni (1989)], Micaria pulicaria (Sundevall, 1831) [Yaginuma (1986), Kamura (1992a)], Zelotes asiaticus (Bösenberg et STRAND, 1906) [ONo et al. (1991)], Zelotes hayashii Kamura, 1987 [Kamura (1987), Matsuda (1988)], Zelotes potanini Schenkel, 1963 [Matsuda (1992)], Drassylus sanmenensis Platnick et Song, 1986 [Kamura (1987c)], Drassodes lapidosus (Walckenaer, 1802) [Yaginuma (1977, 1986), Matsuda (1985), Chikuni (1989)], Drassodes serratidens Schenkel, 1963 [Matsuda (1985, 1992)], Gnaphosa kamurai Ovtsharenko, Platnick et Song, 1992 [Saito (1939), Kamura (1988), Matsuda (1992)], Gnaphosa kompirensis Bösenberg et Strand, 1906 [Yaginuma (1977, 1986), Matsuda (1985, 1988), Kamura (1988), Chikuni (1989)], Callilepis nocturna (Linné, 1758) [MATsuda (1986), Kamura (1987a), Chikuni (1989), Ono et al. (1991)], Kishidaia albimaculata (SAito, 1934) [SAito (1934), Yaginuma (1957, 1960, 1962, 1977, 1986, etc.), Yaginuma \& Ohno (1967), Yaginuma \& NishiKawa (1971), Kamura (1986), Chikuni (1989), Ono et al. (1991)], Sernokorba pallidipatellis (BöSEnberg et STRAND, 1906) [CHIKuni (1989); no collection data from Hokkaido was recorded by Kamura (1992b)], Haplodrassus pugnans (Simon, 1880) [HaYASHI (1984), Matsuda (1987), ChIKUni (1989)] and Poechilochroa hosiziro Yaginuma, 1960 [YAGINUMA (1960, 1977)]. However, these may only be a part of the gnaphosid spiders really occurring there.

Mr. Nobuki YASUDA, Sôunkyô Museum, Kamikawa-chô, Hokkaido, collected

1) Department of Zoology, National Science Museum, Tokyo, 3-23-1 Hyakunin-chô, Shinjukuku, Tokyo, 169 Japan

国立科学博物館動物研究部 T169 東京都新宿区百人町 3-23-1

Accepted December 3, 1994 
insects and spiders by bait trapping in Hokkaido, mainly in the Daisetsuzan Mountains, Central Hokkaido, for many years, and entrusted the spider specimens to the present author. The Daisetsuzan Mountains are composed of some mountains of 1,900-2,300 m alt., showing peculiar natural features with extremely cold climate in Japan, and many alpine insects and other animals are known from the area. Some studies of the families Thomisidae, Clubionidae and Cybaeidae based on the collection of Mr. YASUDA were already published (ONO, 1988, 1991, 1994; ONO \& NiSHIKAWA, 1992; ONO \& YASUDA, 1992). In the present paper 10 species of the spiders of the family Gnaphosidae are reported. Of these, two species of the genera Micaria and Gnaphosa are newly recorded from Japan. All the materials examined in this paper are preserved in the collection of the Department of Zoology, National Science Museum, Tokyo (NSMT).

Before going further, the author wishes to express his sincere thanks to $\mathrm{Mr}$. Nobuki YASUDA, Hokkaido, for offering invaluable specimens, and to Dr. Takahide Kamura, Osaka, and, Mr. Akio TANiKawa, Kanagawa, for critically reading the manuscript of this paper.

\section{Family Gnaphosidae}

\section{Genus Micaria WestRING}

Micaria pulicaria (SundeVAlL, 1831)

Specimen examined. $10^{\top}$, Daisetsu-genseirin, $900 \mathrm{~m}$ alt., Mts. Daisetsuzan, Hokkaido, Japan, 26-VIII-1982, N. YASUDA leg. (NSMT-Ar 3190).

Distribution. Japan (Hokkaido); Holarctic.

Micaria alpina L. KoCH, 1872

(Figs. 5-8)

Micaria alpina L. Косн, 1872, p. 313 (female holotype from Tirol, Austria, ?deposition, not examined)._-LOCKET \& Millidge, 1951, p. 123, fig. 63.-WUNDERLICH, 1979, p. 281, figs. 31, 54.—ROBERTS, 1985, p. 78, fig. 29(c).—ZHANG, 1987, p. 181, fig. 152 (? identification).—Platnick \& Shadab, 1988, p. 18, figs. 30-33.—Heimer \& Nentwig, 1991, p. 434, fig. 1141.—Platnick \& Dondale, 1992, p. 64, figs. 92-95. For other literature see Wunderlich, 1979.

Specimens examined. 107, Mt. Kurodake, 1,980 m alt., Mts. Daisetsuzan, 17IX-1989, N. YASUDA leg. (NSMT-Ar 3191); 1우, same mountain, 1,900 m alt., 27VII-1981, N. YASUdA leg. (NSMT-Ar 3204).

Notes. This species is widely distributed in northernmost part of the Holarctic regions, from Europe to Alaska and Canada. It was recorded also from China (ZHANG, 1987). Therefore, it was accountable that this species occurs in the coldest region of Japan.

The carapace is chestnut brown in female and male; the abdomen of female is grey with two pairs of indistinct white bars, while that of the male is black and polished. Measurement based on the Japanese specimens: Body length 우 $4.25 \mathrm{~mm}$, ơ $3.60 \mathrm{~mm}$.

Distribution. Japan (Hokkaido)—new records-; Holarctic. 


\section{Genus Zelotes GisTEL}

Zelotes asiaticus (BöSENBERG et STRAND, 1906)

Specimens examined. $10^{7}$, Mt. Teshiodake, 1,000 m alt., Asahi-chô, Hokkaido, Japan, 28-VII-1988, N. YASUDA leg. (NSMT-Ar 3187); 1우, Mt. Shokanbetsudake, $450 \mathrm{~m}$ alt., Mashike-gun, Hokkaido, 14-VI-1987, N. YASUDA leg. (NSMT-Ar 3188).

Distribution. Japan (Hokkaido, Honshu, Shikoku, Kyushu); Korea, China.

\section{Zelotes hayashii KAMURA, 1987}

Zelotes hayashii Kamura, 1987, p. 5, figs. 6-7 (male holotype from Nukabira, Kamishihoro-chô, Katô-gun, Hokkaido, Japan, 8-VII-1985, M. MAtsuda leg., in Arachnological Society of Japan, Osaka, not examined).; 1994, p. 135, figs. 1-2.—MATSUdA, 1988, p. 15, figs. 12-13.

Specimen examined. 1우, Mt. Teshiodake, 1,000 m alt., Asahi-chô, Hokkaido, 28-VII-1988, N. YASUdA leg. (NSMT-Ar 3189).

Distribution. Japan (Hokkaido).

\section{Genus Drassyllus ChamberLin}

Drassyllus shaanxiensis Platnick et Song, 1986

Drassyllus shaanxiensis Platnick et Song, 1986, p. 17.--Kamura, 1990, p. 34, figs. 3-6.

Zelotes shaanxiensis: CHIKUNI, 1989, p. 121, fig. 15, p. 251.

Specimens examined. 1우, Rubeshinai, $830 \mathrm{~m}$ alt., Kamikawa-chô, 26-VI-1980, N. YASUDA leg. (NSMT-Ar 3192); 107, Lake Daisetsu, $800 \mathrm{~m}$ alt., Mts. Daisetsuzan, 3-VII-1983, N. YASUdA leg. (NSMT-Ar 3193); 1우, Numanohara, 1,460 m alt., Mts. Daisetsuzan, 29-VII-1986, N. YASUdA leg. (NSMT-Ar 3194).

Distribution. Japan (Hokkaido-new records-, Honshu); China.

\section{Drassyllus sasakawai KAmURA, 1987}

Drassyllus sasakawai KAMURA, 1987, p. 82, figs. 6-9 (male holotype from Ashû, 380 m alt., Miyamachô, Kitakuwata-gun, Kyoto Pref., Japan, 26-28-V-1984, T. Kamura leg., female allotype from Mt. Taiko-yama, $620 \mathrm{~m}$ alt., Yasaka-chô, Yosa-gun, Kyoto Pref., 8-VII-1982, T. KamUra leg., and many paratypes from Kyoto Pref.; all the types in Arachnological Society of Japan, Osaka, not examined).

Specimens examined. 1우, Arashiyama, $240 \mathrm{~m}$ alt., Asahikawa-shi, 5-VII-1988, N. YASUDA leg. (NSMT-Ar 3195); 207, Esaushiyama, $330 \mathrm{~m}$ alt., Kamikawa-chô, 6-VI-1985, N. YASUDA leg. (NSMT-Ar 3196).

Distribution. Japan (Hokkaido-new records-, Honshu, Kyushu).

Genus Drassodes Westring

Drassodes lapidosus (WALCKENAER, 1802)

(Figs. 9-11)

Specimens examined. 2우10`, Mt. Kurodake, 1,980 m alt., Mts. Daisetsuzan, 

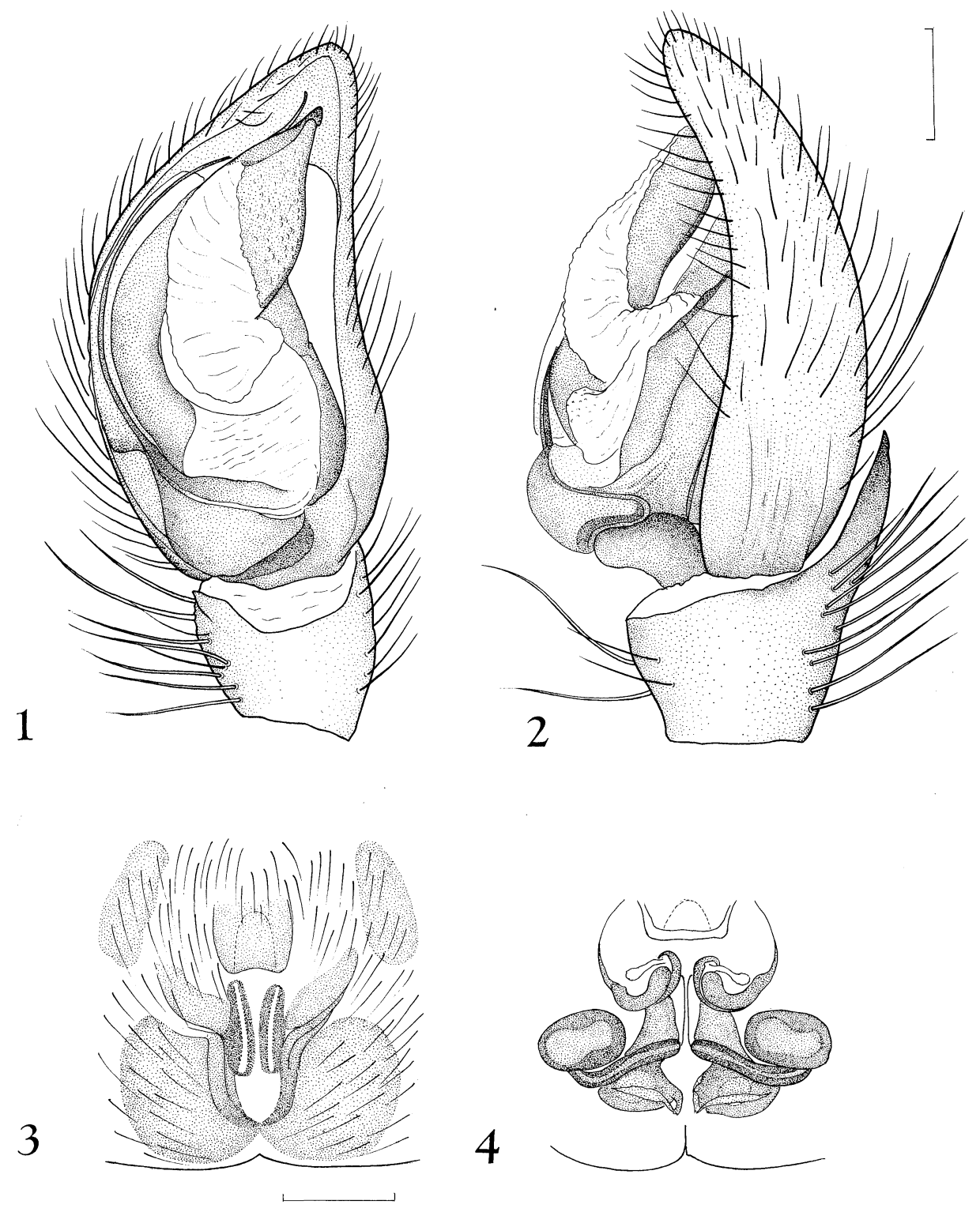

Figs. 1-4. Gnaphosa sticta KULCZYŃSKI, 1908 (NSMT-Ar 3201-3202)._-_1, Male palp, ventral view; 2, same, retrolateral view; 3, epigynum; 4, female genitalia, dorsal view. (Scales: $0.1 \mathrm{~mm}$. )

29-VI-1985, N. Yasuda leg. (NSMT-Ar 3197).

Notes. Minute differences in male tibial apophysis and in the width of 


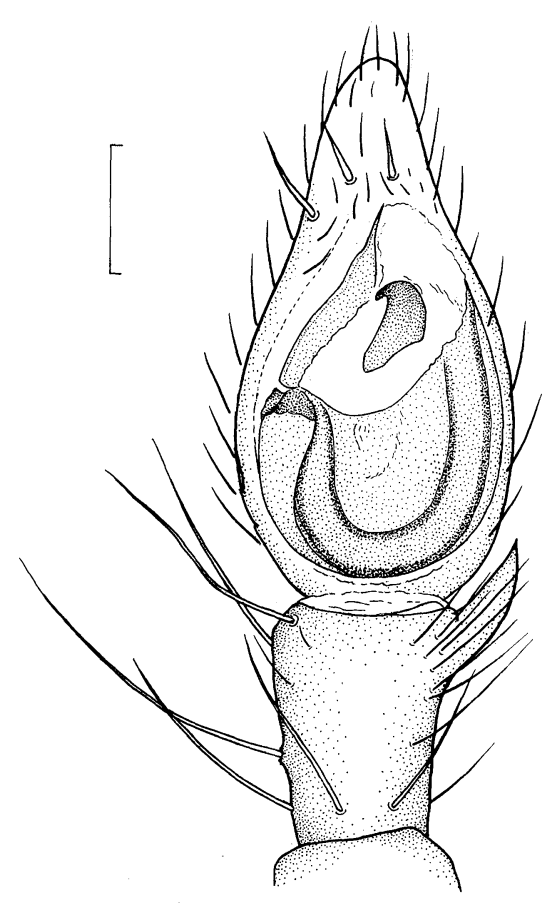

5

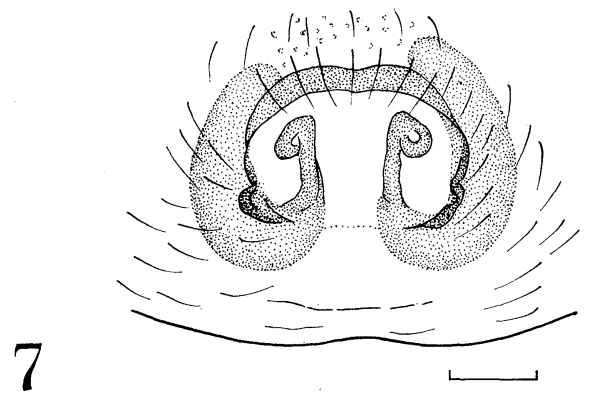

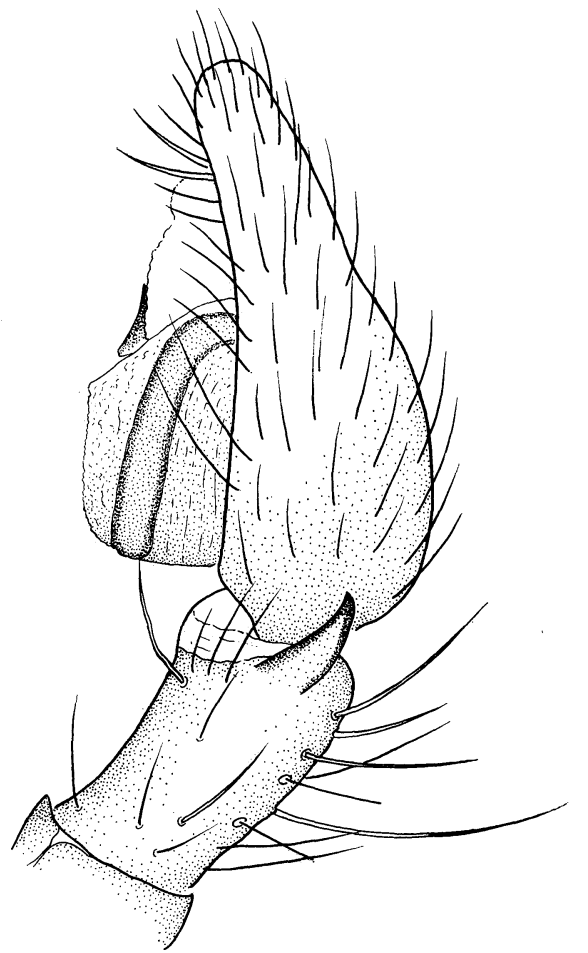

6

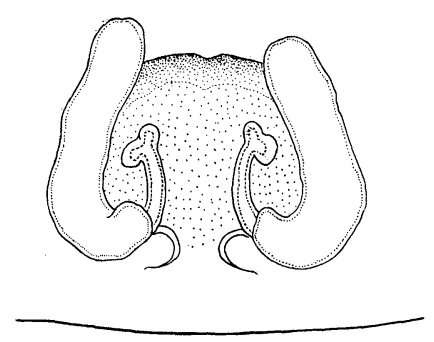

8

Figs. 5-8. Micaria alpina L. KocH, 1872 (NSMT-Ar 3191, 3204)._-1, Male palp, ventral view; 2, same, retrolateral view; 3 , epigynum; 4, female genitalia, dorsal view. (Scales: $0.1 \mathrm{~mm}$.)

epigynum were recognized between the specimens from Hokkaido (Figs. 9-11) and Europe (Grimm, 1985, p. 108, fig. 17, p. 119, fig. 134). However, these may stand in a range of variation.

Distribution. Japan (Hokkaido, Honshu); Palearctic. 

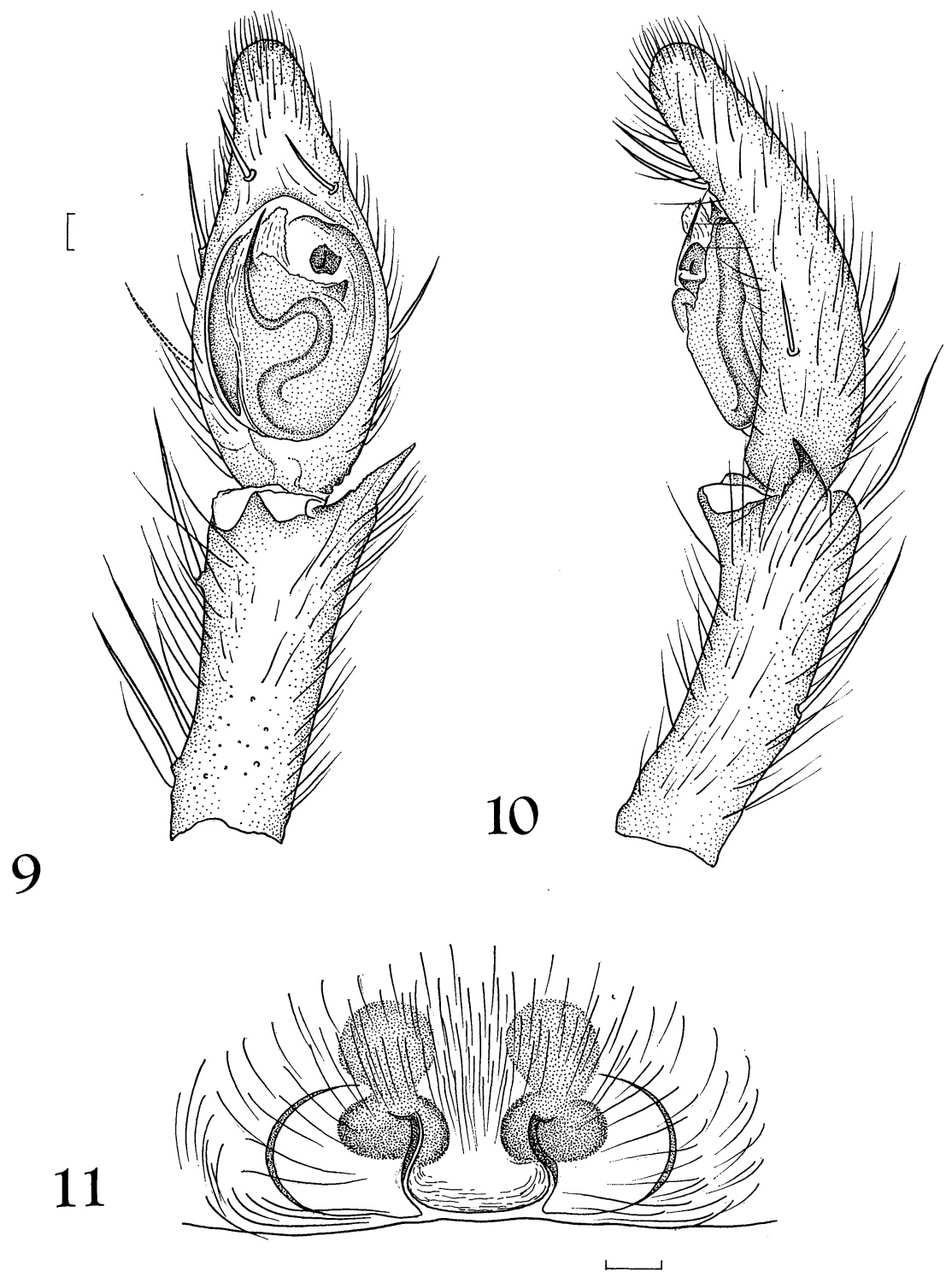

Figs. 9-11. Drassodes lapidosus (WALCKEnAER, 1802) (NSMT-Ar 3197).—-9, Male Palp, ventral view; 10, same, retrolateral view; 11, epigynum. (Scales: $0.1 \mathrm{~mm}$.)

\section{Genus Gnaphosa LATREILLE}

Gnaphosa kompirensis BöSENBERG et STRAND, 1906

Specimen examined. $10^{7}$, Shirakawa, $400 \mathrm{~m}$ alt., Kamikawa-chô, 8-VII-1983, N. YASUDA leg. (NSMT-Ar 3198). 
Distribution. Japan (Hokkaido, Honshu, Shikoku, Kyushu); Russia, Korea, China, Vietnam (Ovtsharenko, Platnick \& Song, 1992).

\section{Gnaphosa kamurai Ovtsharenko, Platnick et Song, 1992}

Gnaphosa compirensis: SAITO, 1939 [misidentification; see KaMURA (1988)].

Gnaphosa alberti: Kamura, 1988, p. 7 (nec Gnaphosa alberti SCHEnKel, 1963).

Gnaphosa kamurai Ovtsharenko, PlatNick et Song, 1992, p. 33, figs. 115-118 (male holotype and female allotype from Machi, $290 \mathrm{~m}$ alt., Ôtsu-shi, Shiga Pref., Japan, 16-VII-1976, Y. NisHIKAWA leg., in Arachnological Society of Japan, Osaka, not examined).

Specimen examined. 1우, Esaushiyama, $380 \mathrm{~m}$ alt., Kamikawa-chô, 19-VII1986, N. YASUdA leg. (NSMT-Ar 3199).

Distribution. Japan (Hokkaido, Honshu).

\section{Gnaphosa sticta KULCZYŃSKI, 1908}

(Figs. 1-4)

Gnaphosa sticta KulCZYŃSKI, 1908, p. 7, fig. 4 (female holotype from Yakutiya, Russia, in Academy of Sciences, St. Petersburg, not examined). Ovtsharenko \& Marusik, 1988, p. 208, figs. 16-17, 20.-Ovtsharenko, Platnick \& Song, 1992, p. 48, figs. 163-168.

Gnaphosa intermedia Holm, 1939, p. 11, fig. 5 [described from Lappland; synonymized by OvTSHARENKo \& MARUSIK (1988)].

Gnaphosa microps: Holm, 1950, p. 136, fig. 8.

Specimens examined. 3우, Mt. Hirayama, 1,740 m alt., Mts. Daisetsuzan, 8VIII-1980, N. Yasuda leg. (NSMT-Ar 3200); 10', Mt. Nipesotsu, 2,010 m alt., Mts. Daisetsuzan, 3-VII-1988, N. YASUdA leg. (NSMT-Ar 3201); 2우, Mt. Tottabetsu, 1,960 m alt. Mts. Hidaka, 21-VII-1988, N. YASUDA leg. (NSMT-Ar 3202).

Notes. This species was hitherto known only from the northeastern part of Siberia (Ovtsharenko, Platnick \& Song, 1992). On the basis of the comparison between the copulatory organs of both the sexes of the present materials from Japan (Figs. 1-4) and the figures made by Ovtsharenko, Platnick \& Song (1992, figs. 163-166) I determined the Japanese spider to be same species as the Russian one. It is new to the Japanese fauna.

The females of the Japanese specimens have brown prosoma and blackish brown opisthosoma, while the only male collected is much darker than the females. Measurement based on the Japanese materials: Body length 우 $6.70-7.55 \mathrm{~mm}$, o $6.65 \mathrm{~mm}$.

Distribution. Japan (Hokkaido)—new records-; Russia (Siberia).

\section{Genus Callilepis WeSTRING}

Callilepis nocturna (LINNÉ, 1758)

Specimen examined. 1우, Shirakawa, $400 \mathrm{~m}$ alt., Kamikawa-chô, 31-V-1983, N. YASUDA leg. (NSMT-Ar 3203).

Distribution. Japan (Hokkaido); Palearctic. 


\section{摘 要}

おもに大雪山からベートトラップ法により得られた北海道のワシグモ科クモ類 10 種を 記録した。このうち Drassyllus shaanxiensis PlatNICK et Song, 1986 チクニヨリメケム リグモおよび D. sasakawai KAMURA, 1987 ヤマヨリメケムリグモを北海道から新たに記 録した。 また Micaria alpina L. KocH, 1872 タカネッヤグモ（新称）とGnaphosa sticta KULCZYŃSKI, 1908 シベリアメキリグモ（新称）の 2 種を日本から初めて記録した。前種 は全北区の北部に広く分布し, 後種はシベリアの東北部と北海道からのみ知られる.

\section{References}

BösenberG, W., \& E. Strand, 1906. Japanische Spinnen. Abh. senckenbg. naturf. Ges., 30: 93$373,400-422$, pls. 3-16.

ChIKuni, Y., 1989. Pictorial Encyclopedia of Spiders in Japan. 308 pp. Kaiseisha, Tokyo. (In Japanese.)

Grimm, U., 1985. Die Gnaphosidae Mitteleuropas (Arachnida, Araneae). Abh. naturw. Ver. Hamburg, (N.F.), 26: 1-318.

Hayashi, T., 1984. Drassodes lapidosus (Walckenaer, 1802) and Haplodrassus signifer (C. L. Косн, 1839). Atypus, (85): 9-18. (In Japanese, with English synopsis.)

Heimer, S., \& W. NenTwig, 1990. Spinnen Mitteleuropas. 543 pp. Paul Parey, Berlin and Hamburg.

Holm, Å., 1939. Neue Sipnnen aus Schweden. Beschreibung neuer Arten der Familien Drassidae, Theridiidae, Linyphiidae und Micryphantidae. Ark. Zool., 31A(8): 1-38. (Non vidi.)

__ 1950. Studien über die Spinnenfauna des Torneträskgebietes. Zool. Bidr. Uppsala, 29: 103-213. (Non vidi.)

Kamura, T., 1984. Notes on Japanese gnaphosid spiders (I). Atypus, (85): 1-8. (In Japanese.)

___ 1986. Notes on Japanese gnaphosid spiders (II). Ibid., (87): 9-20. (In Japanese.)

- 1987a. Notes on Japanese gnaphosid spiders (III). Callilepis nocturna (Linnaeus) and Zelotes potanini SCHENKel. Ibid., (89): 1-6. (In Japanese.)

- $-1987 \mathrm{~b}$. Two new species of the genus Zelotes (Araneae: Gnaphosidae) from Japan. Akitu, (Publ. Kyoto ent. Soc.), n. ser., (85): 1-7.

- $1987 \mathrm{c}$. Three species of the genus Drassyllus (Araneae: Gnaphosidae) from Japan. Acta arachnol., 35: 77-88.

___ 1988. A revision of the genus Gnaphosa (Araneae: Gnaphosidae) from Japan. Akitu, (Publ. Kyoto ent. Soc.), n. ser., (97): 1-14.

- - - 1990. Notes on Japanese gnaphosid spiders (IV). One newly recorded species and two little-known species of Japan. Atypus, (95): 32-38. (In Japanese.)

- 1992 a. Notes on Japanese gnaphosid spiders (V). Three rare species in Japan. Ibid., (100): 17-22. (In Japanese.)

_- $1992 \mathrm{~b}$. Two new genera of the family Gnaphosidae (Araneae) from Japan. Acta arachnol., 41: 119-132.

- _ - 1994. A description of the female of Zelotes hayashii Kamura, 1987 (Araneae: Gnaphosidae). Acta arachnol., 43: 135-137.

KocH, L., 1872. Beitrag zur Kenntniss der Arachnidenfauna Tirols. Zweite Abhandlung. Zeits. Ferd. Tirol Voralbg., (3), 17: 239-328. (Non vidi.)

KulCZYŃSkI, W., 1908. Araneae et Oribatidae. Expeditionum rossicarum in insulas NovoSibiricas annis 1885-1886 et 1900-1903 susceptarum. Mém. Acad. imp. Sci. St. Pétersbourg, (8), 18(7): 1-2, 1-97, 1-3, pls. 1-3.

Locket, G. H., \& A. F. Millidge, 1951. British Spiders, Vol. 1. x+310 pp. Ray Society, London. Matsuda, M., 1985. A list of spiders of the Central Mountain District (Taisetsuzan National 
Park), Hokkaido. Bull. Higashi Taisetsu Mus. nat. Hist., (7): 1-33. (In Japanese, with English abstract.)

Matsuda, M., 1986. Supplementary note to "a list of spiders of the Central Mountain District (Taisetsuzan National Park), Hokkaido.” Ibid., (8): 83-92. (In Japanese.)

- 1987. Spiders of the Tokachi Plain, Hokkaido, Japan (1). Ibid., (9): 15-33. (In Japanese.) 1988. Supplementary note (2) to "a list of spiders of the Central Mountain District (Taisetsuzan National Park), Hokkaido." Ibid., (10): 11-18. (In Japanese.)

1992. Spiders of the Tokachi Plain, Hokkaido, Japan (2). Ibid., (14): 97-101. (In Japanese, with English summary.)

Ono, H., 1988. A Revisional Study of the Spider Family Thomisidae (Arachnida, Araneae) of Japan. ii $+252,1$ col. pl. National Science Museum, Tokyo.

1991. Two interesting species of the genus Clubiona (Araneae, Clubionidae) from Hokkaido, Japan. Bull. natn. Sci. Mus., Tokyo, 17: 139-143.

1994. Two species of the spider genus Clubiona (Araneae: Clubionidae) new to the Japanese fauna. Acta arachnol., 43: 37-41.

-, K.-i. Kumada, M. Sadamoto \& E. Shinkai, 1991. Spiders from the northernmost areas of Hokkaido, Japan. Mem. natn. Sci. Mus., Tokyo, (24): 81-103.

\& Y. NishikawA, 1992. Records of spiders from the northernmost areas of Hokkaido, Japan, with notes and illustrations of Cybaeus kunashirensis (Araneae, Cybaeidae). Mem. natn. Sci. Mus., Tokyo, (25): 135-142.

\& N. YASUDA, 1992. Records of thomisid spiders (Arachnida, Araneae) from Hokkaido, Japan. Bull. Sounkyo Mus. nat. Hist., (12): 1-13. (In Japanese, with English summary.)

Ovtsharenko, V. I., \& Y. M. Marusik, 1988. Spiders of the family Gnaphosidae (Aranei) of the North-East of the USSR (the Magadan Province). Ent. Obozr., 67: 204-217. (In Russian.)

- N. I. Platnick \& D. X. Song, 1992. A revision of North Asian ground spiders of the genus Gnaphosa (Araneae, Gnaphosidae). Bull. Amer. Mus. nat. Hist., (212): 1-88.

Platnick, N. I., \& C. D. Dondale, 1992. The Insects and Arachnids of Canada, Part 19. The Ground Spiders of Canada and Alaska. Araneae: Gnaphosidae. 297 pp. Minister of Supply and Services Canada, Ottawa.

\& M. U. ShadAb, 1988. A revision of the American spiders of the genus Micaria (Araneae, Gnaphosidae). Amer. Mus. Novitates, (2916): 1-64.

SAIto, S., 1934. Spiders from Hokkaido. J. Fac Agr. Hokkaido imp. Univ. Sapporo, 33: 267-362. 1939. On the spiders from Tohoku (northernmost part of the main island), Japan, Saito Hoon-kai Mus. Res. Bull., 3: 1-91.

Wunderlich, J., 1979. Revision der europaischen Arten der Gattung Micaria Westring 1851, mit Anmerkungen zu den übrigen paläarktischen Arten (Arachnida: Araneida: Gnaphosidae). Zool. Beitr., N. F., 25: 233-341.

Yaginuma, T., 1957. Spiders from Hakkaido and Rishiri Island. Acta arachnol., 14: 51-61, pls. III-IV. (In Japanese, with Englich summary.) 1960. Spiders of Japan in Colour. vi+186 pp., 56 pls. Hoikusha, Osaka. (In Japanese, with some English descriptions.)

1962. The Spider Fauna of Japan. $74+18$ pp., pls. I-II. Arachnol. Soc. East Asia, Osaka.

1977. A list of Japanese spiders (revised in 1977). Acta arachnol., 27 (special number): 367-406. (In Japanese, with English summary.)

1986. Spiders of Japan in Color (new edition). xxiv +305 , pls. 1-64. Hoikusha, Osaka. (In Japanese.)

\& Y. Nishikawa, 1971. Spiders of Mt. Daisetsu, Hokkaido. In: Faunal Survey of the Mt. Daisetsu Area, JIBP Main Area, VI, pp. 71-96. (In Japanese, with English summary.)

\& M. OHNo, 1967. The spiders from the islands belonging to Hokkaido, Japan. J. Toyo Univ. gen. Educ., (nat. Sci.), (8): 13-29. (In Japanese, with English abstract.)

Zhang, W. S. (ed.), 1987. Farm Spiders from Hebei Province. 299 pp. Hebei Sci. Tech. Press, Shijiazhuang. 